\title{
Physiological and Morphological Responses of Jatobá Submitted to Weed Competition and Glyphosate Doses
}

\author{
Luiz Felipe R. Oliveira ${ }^{1}$, Reynaldo C. Santana ${ }^{1}$, José B. dos Santos ${ }^{2}$, Bruno O. Lafetá ${ }^{3}$ \\ \& Carolina M. M. B. Chaves ${ }^{1}$ \\ ${ }^{1}$ Department of Forest Engineering, Universidade Federal dos Vales do Jequitinhonha e Mucuri, Diamantina, \\ Brazil \\ ${ }^{2}$ Department of Agronomy, Universidade Federal dos Vales do Jequitinhonha e Mucuri, Diamantina, Brazil \\ ${ }^{3}$ Department of Forest Engineering, Istituto Federal de Minas Gerais, São João Evangelista, Brazil \\ Correspondence: Luiz Felipe R. Oliveira, Department of Forest Engineering, Universidade Federal dos Vales do \\ Jequitinhonha e Mucuri, Campus JK, Highway MGT 367-Km 583, n 5000, Diamantina, MG, 39100-000, Brazil. \\ Tel: 55-339-976-6156. E-mail: luizfelipe.florestal@gmail.com
}

$\begin{array}{lcc}\text { Received: April 8, } 2019 & \text { Accepted: May 11, } 2019 & \text { Online Published: July 15, } 2019 \\ \text { doi:10.5539/jas.v11n10p172 } & \text { URL: https://doi.org/10.5539/jas.v11n10p172 }\end{array}$

\begin{abstract}
The jatobá (Hymenaea courbaril L.) occurring throughout Central America and tropical countries in South America. This specie has great potential timber, in addition to fruits, leaves and bark with medicinal properties. This study was conducted to evaluate the effect of weed competition and intoxication by glyphosate in jatobá plants. The experiment was carried out with jatobá plants in field. Eleven months after planting it was held a floristic inventory in the area. One month after thisfloristic inventory, it was installed an experimental design with six randomized blocks and six treatments: manual weeding of weeds; no manual weeding or herbicide; and four glyphosate doses, 1.25, 2.5, 3.75 and 5.00 $\mathrm{L} \mathrm{ha}^{-1}$. At 15, 30, 45, 60 and 90 days after tratment it was carried out a photochemical efficiency analysis of photosystem II, chlorophyll indices, number of leaflets, height and stem diameter of the plants. Based on physiological variables $\left(\mathrm{F}_{0}, \mathrm{~F}_{\mathrm{m}}, \mathrm{F}_{\mathrm{v}} / \mathrm{F}_{\mathrm{m}}\right.$ and ETR), the jatobá plants recovered 60 days after treatments. Although the jatobá plants are tolerant to glyphosate and weed competition, jatobá plants under 1.25 and $2.50 \mathrm{~L} \mathrm{ha}^{-1}$ of glyphosate reduces the increase in height around $50 \%$, plants under 3.75 and $5.00 \mathrm{~L} \mathrm{ha}^{-1}$ reduces around $90 \%$ and plants under weed competition around $70 \%$.
\end{abstract}

Keywords: chlorophyll a fluorescence, herbicides, Hymenaea courbaril, herbicide tolerance, photosystem II

\section{Introduction}

The jatobá (Hymenaea courbaril L.) occurring throughout Central America and tropical countries in South America (Costa, A. L. Souza, \& P. B. Souza, 2011). It has great potential timber (Costa et al., 2011), in addition to fruits, leaves and bark with medicinal properties (Miyake et al., 2008). This species has a significant seed production (Campos \& Uchida 2002) with a high percentage of germination and seedling production (Souza et al., 2013; 2015). It can be propagated via seminal directly in the field or in containers (Souza et al., 2013), it adapts to different climatic and soil conditions (Costa et al., 2011), it can even be used in the recovery of degraded areas (Zuba-Júnior et al., 2010).

Due to the territorial comprehensiveness and commercial potential that jatobá features, this is a species with great interest of domestication. An important silvicultural factor for the domestication of a forest species is its adaptation to competition with weeds (Campoe et al., 2014). Plants sensitive to competition require major investments in control of weed competition, whether done by manual weeding or by the use of herbicides.

Among the herbicides, glyphosate stands out as the most used in the world (Gianessi, 2008). This herbicide has systemic action and acts in a non-selective manner, so it is capable to control several weed species. However, if you come into accidental contact with the culture, can cause injuries, morphological changes, nutritional deficiencies, reduction in chlorophyll content, loss of growth and, in extreme cases, death of plants (Costa et al., 2009; Zobiole, Kremer, Oliveira-Júnior, \& Constantin, 2011). Therefore, it is necessary to identify the damage caused by this herbicide in the event of inadequate application, common situation in field conditions (Zobiole et al., 2011). 
In greenhouse conditions, low sensitivity of jatobá plants to glyphosate rates of up to $0.70 \mathrm{~L} \mathrm{ha}^{-1}$ were observed (Gandini, Santos, Gandini, Santanna, \& Silva, 2014). These authors concluded that the damage caused by glyphosate may not be visible or difficult to identify. Thus, the measurement of physiological responses of the cultures becomes an alternative to evaluate them. Among the diverse evaluation methods stand out measurements of photosystem efficiency II (PSII), gas exchange, chlorophyll content and electron transport rate (Maxwell \& Johnson, 2000; Baker, 2008).

The study of the PSII efficiency parameters allows the analysis of absorption and utilization of light energy in the PSII by plants (Baker, 2008). The light is absorbed mainly by chlorophyll that when excited it can dissipate the energy as fluorescence (Maxwell \& Johnson, 2000; Baker, 2008). Plants under various types of stress alter the shape and the amount of this energy dissipation directly affecting photosynthesis (Baker, 2008; Olesen \& Cedergreen, 2010; Yanniccari, Tambussi, Istilart, \& Castro, 2012; Feng et al., 2018). Thus, this study was conducted to evaluate the effect of weed competition and intoxication by glyphosate in jatobá plants.

\section{Method}

\subsection{Experimental Site}

The experiment was conducted using jatobá plants in spatial arrangement of $3 \times 2 \mathrm{~m}$ in an area of $1000 \mathrm{~m}^{2}$ of flat terrain, located at Fazenda Experimental Rio Manso in Couto de Magalhães de Minas-Minas Gerais with centroid at coordinates $18^{\circ} 4.591^{\prime} \mathrm{S}$ and $43^{\circ} 27.401^{\prime} \mathrm{W}$. The site has temperature and mean annual precipitation of $19.4^{\circ} \mathrm{C}$ and $1269 \mathrm{~mm}$ respectively, with climate Aw by Köppen classification (Kottek, Grieser, Beck, Rudolf, \& Rubel, 2006), characterized as tropical savanna with a dry season of winter.

\subsection{Jatobá Planting}

The plants were obtained from seeds collected from six progenies of the municipalities of Curvelo, São Gonçalo do Rio Preto and Couto de Magalhães de Minas-Minas Gerais. To break dormancy, seeds were scarified with 220 sandpaper and manually sown in soil holes in January 2012 in Ustox Oxisol (Table 1). The weed control was performed in a radius of $50 \mathrm{~cm}$ from the place where the seeds were placed.

Table 1. Chemical and physical analysis of the soil at the trial site

\begin{tabular}{|c|c|c|c|c|c|c|c|c|c|c|c|}
\hline $\mathrm{pH}$ & $\mathrm{P}$ & K & $\mathrm{H}+\mathrm{Al}$ & $\mathrm{Al}$ & $\mathrm{Ca}$ & $\mathrm{Mg}$ & O.M. & $\mathrm{m}$ & Sand & Silt & Clay \\
\hline $\mathrm{H}_{2} \mathrm{O}$ & $---m$ & $\mathrm{~m}^{-3}---$ & -----. & $---\mathrm{cl}_{1}$ & $\mathrm{dm}^{-3}$ & -------- & dag $\mathrm{kg}^{-1}$ & ----- & - & ----- & ------- \\
\hline 4.89 & 1.36 & 45.4 & 3.89 & 0.07 & 0.10 & 0.04 & 1.36 & 21.7 & 45 & 29 & 26 \\
\hline
\end{tabular}

Note. pH: $\mathrm{H}_{2} \mathrm{O}$; P, K: Extractant Mehlich-1; $\mathrm{Ca}, \mathrm{Mg}$, Al: Extractant $\mathrm{KCl} 1 \mathrm{~mol} \mathrm{~L}^{-1}$; H+Al: Extractant SMP; O.M: Oxidation $\mathrm{Na}_{2} \mathrm{Cr}_{2} \mathrm{O}_{7} 0.67 \mathrm{~mol} \mathrm{~L}^{-1}+\mathrm{H}_{2} \mathrm{SO}_{4} 5 \mathrm{~mol} \mathrm{~L}^{-1}$; Sand, silt, clay: pipette method.

\subsection{Floristic Inventory}

The jatobá plants were conducted for 12 months under the same conditions, carrying out frequent mowing in order to reduce the height of the weeds during the first year. As the planting area was previously used as grasslands, for weed competition characterization it was held a floristic inventory in December 2012. It was used as plot a square $(50 \times 50 \mathrm{~cm})$ randomly allocated 15 times in the study area. At each allocated plot the species were identified and was calculated the frequency relative (Frr, number of plots with the species divided by the total number of plots multiplied by 100 divided by the total frequency of all species); relative density (Drr total number of individuals per species divided by the total sampled area, multiplied by 100 divided by the total density of species); relative abundance (Abr, total number of individuals per species divided by the total number of plots with the species, multiplied by 100 divided by the total abundance of species) and the importance value index (IVI, sum of the Frr, Drr, Abr) (Mueller-Dombois \& Ellenberg, 1974).

\subsection{Experimental Designed}

After 30 days of phytosociological evaluation it was proceeded the application of treatments. We used a randomized block design with six blocks and six treatments: manual weeding the weeds without the use of glyphosate (MW); applying glyphosate at $\mathrm{L} \mathrm{h}^{-1}, 1.25 ; 2.50 ; 3.75$; and 5.00 , besides the control in which neither the glyphosate was applied nor the manual weeding proceeded (WC). The establishment of these doses was based on the product commercial recommendation for eucalyptus, considering that for jatobá culture there is no regulated herbicide. Glyphosate was applied with a sprayer backpack pressurized to $\mathrm{CO}_{2}$, at constant pressure of 
$200 \mathrm{kPa}$, equipped with a bar of two air induction nozzles TTI $11002 \mathrm{bar}$, at $50 \mathrm{~cm}$ of jatobá heights with a speed of $1 \mathrm{~m} \mathrm{~s}^{-1}$, reaching an application range of $100 \mathrm{~cm}$ in width and spray volume of $200 \mathrm{~L} \mathrm{ha}^{-1}$.

\subsection{Physiological and Morphological Evaluations}

At 15, 30, 45, 60 and 90 days after treatments (DAT) it was conducted an analysis of the photochemical efficiency of photosystem II (PSII), chlorophyll a indices (Chla), b (Chlb) and total (ChlT), number of leaflets, height $(\mathrm{cm})$ stem diameter $(\mathrm{mm})$ plants. The PSII efficiency analysis was performed by a fluorometer (PAM-2000, Waltz, Germany), chlorophyll contents by ClorofiLOG1030® (Falker Agricultural Automation, Brazil), the number of leaflets by manual counting, the height was measured from the ground up to the last apical bud of plants and obtained using a millimeter tape and stem diameter obtained by a digital caliper. All leaf analyzes were obtained from leaves fully expanded in the middle third of the tree canopy.

The measurements of the PSII efficiency were performed after 30 minutes of dark adaptation of the leaves, with issuance of a saturating light pulse of 0.3 seconds, in frequency $0.6 \mathrm{kHz}$, obtaining the initial fluorescence $\left(\mathrm{F}_{0}\right.$, electrons quantum $\left.{ }^{-1}\right)$, maximal fluorescence $\left(\mathrm{Fm}\right.$, electrons quantum $\left.{ }^{-1}\right)$, maximum quantum yield of PSII $\left(\mathrm{F}_{\mathrm{v}} / \mathrm{F}_{\mathrm{m}}\right)$ and electron transport rate (ETR $\mu \mathrm{mols}$ electrons $\mathrm{m}^{-2} \mathrm{~s}^{-1}$ ). The number of leaflets, height and diameter of the plants were transformed into relative values aiming the standardization of these variables. Thus, before the treatments these variables were measured. The initial number of leaflets was converted into $0 \%(\mathrm{nF})$, and values higher than 0 indicate the percentage of the leaflets gain of the plant and lower values indicate a loss. The height and diameter were transformed into percentage increments according to equations (1) and (2). All variables were subjected to analysis of variance $5 \%$ significance when significant they were submitted to the Scott Knott test also at 5\% significance. All statistical analyzes were performed with R software Core Team (2018), with the help of R Studio version 0.98 .1103 platform.

$$
\begin{aligned}
& \mathrm{ICH}=[(\mathrm{H} f-\mathrm{H} i) / \mathrm{H} f] \times 100 \\
& \mathrm{ICD}=[(\mathrm{D} f-\mathrm{D} i) / \mathrm{D} f] \times 100
\end{aligned}
$$

where, ICH: increase in height (\%); H: height (cm); f: final; $i$ : initial; ICD: increase in diameter (\%); D: diameter (mm).

\section{Results}

In the floristic inventory, 12 weed species were found (Figure 1). Among the weed species stand out with higher importance value index (IVI) the Diodia teres (Walter) Small, Mimosa hirsutissima Mart. and Brachiaria decumbens Stapf. B. decumbens was the specie that showed higher frequencies (Frr), followed by D. teres which has the greatest relative density (Drr), relative abundance (Abr) and IVI.

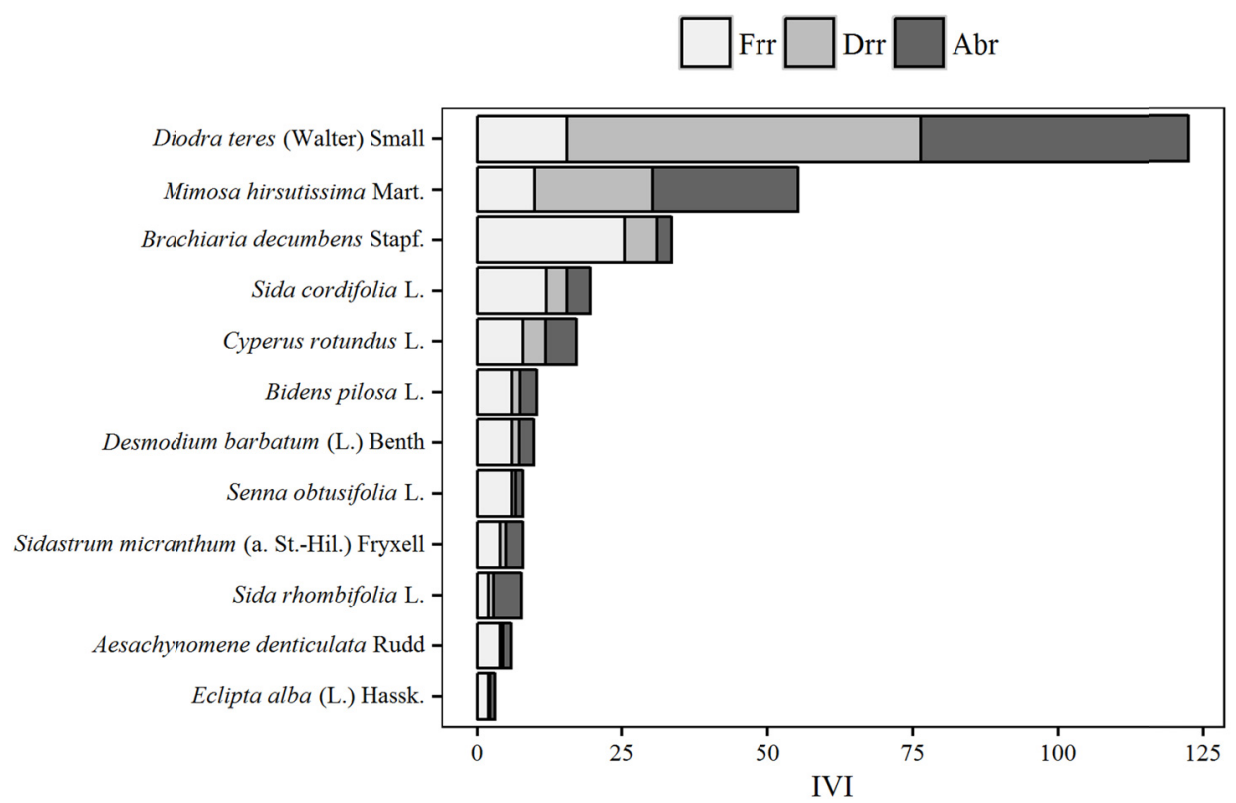

Figure 1. Floristic inventory in jatobá area. Frr: Relative frequence; Drr: Relative density; Abr: Relative abundance; IVI: Importance value index 
Regarding the jatobá, the initial chlorophyll fluorescence $\left(\mathrm{F}_{0}\right)$ increased in plants treated with glyphosate doses 15 DAT (Figure 2A). The maximum quantum yield of PSII $\left(\mathrm{F}_{\mathrm{v}} / \mathrm{F}_{\mathrm{m}}\right)$ followed a similar behavior. However, there was no difference in plants under 1.25 and $3.75 \mathrm{~g} \mathrm{~L}^{-1}$ doses to plants that were not applied the glyphosate (manual weeding and weed competition) (Figure 2C).
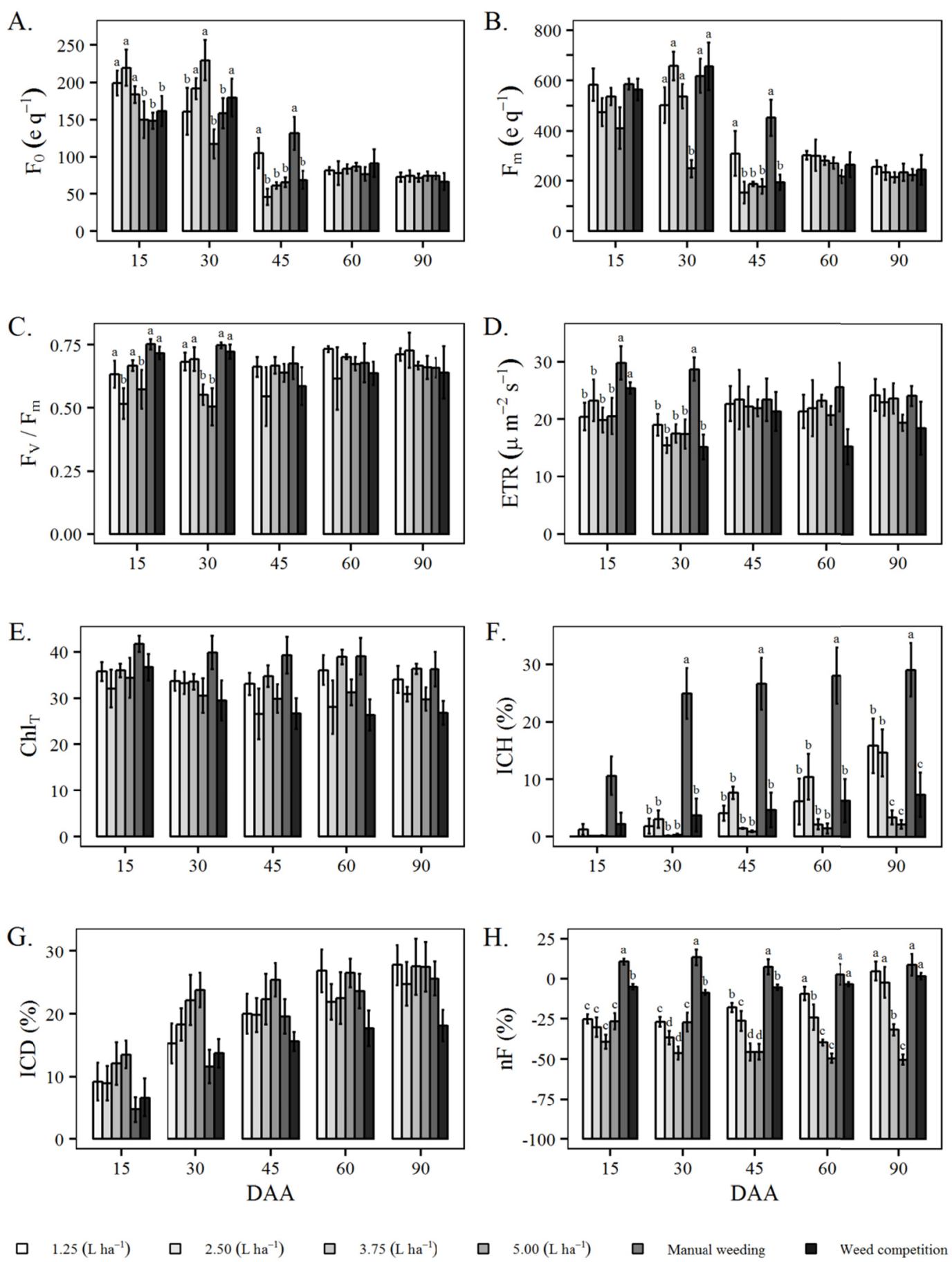

Figure 2. Average and standard error of the treatments for the studied variables. $\mathrm{F}_{0}$ : Initial fluorescence; $\mathrm{F}_{\mathrm{m}}$ : Maximal fluorescence; $\mathrm{F}_{\mathrm{v}} / \mathrm{F}_{\mathrm{m}}$ : Maximum quantum yield of photosystem II; ETR: Electron transport rate; $\mathrm{Chl}_{\mathrm{T}}$ : Chlorophyll total index; ICH: Percentage increase in height; ICD: Percentage increase in diameter; nF: Relative leaflets number. Different letters in the columns indicate that the treatments differ on average by Scott Knott test at $5 \%$ significance 
30 DAT, plants under manual weeding and weed competition presented $\mathrm{F}_{0}$ equivalent to those that were applied 1.25 and $5.00 \mathrm{~L} \mathrm{ha}^{-1}$ of glyphosate (Figure 2A). Plants treated with the highest dose of glyphosate (5.00 L ha $\left.{ }^{-1}\right)$ had maximal fluorescence $\left(\mathrm{F}_{\mathrm{m}}\right)$ statistically lower than plants under others treatments (Figure 2B). Not always absolute changes in $\mathrm{F}_{0}$ and $\mathrm{F}_{\mathrm{m}}$ values indicate changes in PSII reactions centers (Figures 2A and 2B). Only plants under higher doses of glyphosate (3.75 and $5.00 \mathrm{~L} \mathrm{ha}^{-1}$ ) showed Fv/Fm below plants under lower doses, manual weeding and weed competition (Figure 2C).

Among the physiological variables, only $\mathrm{F}_{0}$ and $\mathrm{F}_{\mathrm{m}}$ presented difference between treatments at 45 DAT (Figures $2 \mathrm{~A}$ and $2 \mathrm{~B}$ ). Plants under manual weeding showed $\mathrm{F}_{0}$ and $\mathrm{F}_{\mathrm{m}}$ statistically equal to plants under $1.25 \mathrm{~L} \mathrm{ha}^{-1}$ of glyphosate. Smaller absolute differences of physiological variables indicate a slight physiological recovery of plants under these treatments. However, there was a huge difference between plants under manual weeding and under others treatments by ICH at 45 DAT (Figure 2F).

None of the treatments differed by physiological variables, chlorophyll levels and an increase in diameter (ICD) at 60 and 90 DAT (Figures 2E and 2G). At 90 DAT, Plants under manual weeding showed higher ICH (Figure 2F). Plants under lower doses of glyphosate $\left(1.25\right.$ and $\left.2.50 \mathrm{~L} \mathrm{ha}^{-1}\right)$ presented higher ICH than plants under 3.75 and 5.00 L ha ${ }^{-1}$ doses of glyphosate and weed competition. Only plants under 3.75 and $5.00 \mathrm{~L} \mathrm{ha}^{-1}$ of glyphosate presented $\mathrm{nF}$ significantly reduced.

\section{Discussion}

Since $B$. decumbens had been used as pasture on the site, it was expected it frequency around one (Figure 1). However, $B$. decumbes was not found in all squares in floristic inventory. The higher Drr, Abr and IVI of D. teres and $M$. hirsutissima than $B$. decumbens highlights their competitive capacity. Aggressive characteristics of $D$. teres and M. hirsutissima are known and stand out when they are present in high intense pastures, preferably on sandy soils (Lorenzi, 2008), being able to completely dominate the established pasture. Moreover, these weeds aggressive characteristics can compromise the native tree initial growing (Hartmann, Fortes, Cassol, Valmorbida, \& Mendonça, 2017).

The increase in $\mathrm{F}_{0} 15$ DAT may indicate structural damage to PSII reaction centers or the impairment in the antenna complex power transmission to reaction centers of jatobá leaves (Bolhar-Nordenkampf et al., 1989). Probably so, it was found lower values in the electron transport rate (ETR) and relative number of leaflets (nF) in plants under glyphosate doses (Figure 2D, H). Reductions in ETR and $\mathrm{F}_{\mathrm{v}} / \mathrm{F}_{\mathrm{m}}$ ratio in jatobá plants under glyphosate doses may be associated with an increase in the non-photochemical quenching coefficient (Rochaix, 2011). In another words, plants under stress as caused by this herbicide dissipate most of the energy absorbed as heat and do not use this energy in photosynthesis (Baker, 2008).

Stress, as caused by glyphosate doses, can change leaf optical characteristics and that changes may result plant physiological changes, making it difficult interpretation by $\mathrm{F}_{0}$ and $\mathrm{F}_{\mathrm{m}}$ variables (Baker, 2008). However, when plants are under any stress, the $\mathrm{F}_{\mathrm{v}} / \mathrm{F}_{\mathrm{m}}$ ratio becomes a significant indicator of the inhibitory effect of PSII (Maxwell \& Johnson, 2000; Baker, 2008; Feng et al., 2018). The Fv/Fm ratio ranging from 0.75 to 0.85 indicate that the plants are under some kind of stress (Bolhar-Nordenkampf et al., 1989). Thus, apart from the manual weeding treatment, all plants showed $\mathrm{F}_{\mathrm{v}} / \mathrm{F}_{\mathrm{m}}$ in stressful conditions at 30 DAT (Figure 2C).

Moreover, the stress ratio can be better analyzed by ETR together $F_{v} / F_{m}$ (Figure 2D). A decreased value of $F_{v} / F_{m}$ indicated problems in ETR and subsequently damages to photosynthetic structures (Feng et al., 2018). Probably, the lower ETR in plants under glyphosate doses at 15 and 30 DAT were related to one of the glyphosate indirect effects in photosynthesis, which reduce the ATP synthesis and consequently incorporate less carbon (Malkin \& Niyogi, 2000). The morphologic characteristics such as $\mathrm{nF}$, ICD and ICH reflect the lower carbon incorporation in jatobá plants (Figures $2 \mathrm{~F}, 2 \mathrm{G}$, and $2 \mathrm{H}$ ). It was observed that the plants exempted from the application of glyphosate (manual weeding and weed competition) had larger $\mathrm{nF}$, as well as plants that were performed manual weeding had higher ICH at 60 and 90 DAT.

Denser plant spacings in mixed plantations did not affect the jatobá growth (Zuba-Junior et al., 2010), and in early stages of development (130 days) the jatobá plants were compromise in height growth under weed and consort plants competition for 60 days (Gandini et al., 2011). However, in the field under natural competitive environment (Figure 1), the weed competition effects were so harmful to jatobá ICH as treatments of the highest glyphosate doses (Figure 2).

Jatobá plants under 1.25 and $2.50 \mathrm{~L} \mathrm{ha}^{-1}$ glyphosate doses recover at $90 \mathrm{DAT}$ and presented ICH and $\mathrm{nF}$ highest than plants under 3.75 and $5.00 \mathrm{~L} \mathrm{ha}^{-1}$ and weed competition (Figures $2 \mathrm{~F}$ and $2 \mathrm{H}$ ). Similar immediately ICH 
reduced caused by glyphosate in other tree species were reported also (Costa et al., 2009). However, for jatobá seedlings glyphosate doses of up to $0.70 \mathrm{~L} \mathrm{ha}^{-1}$ provide no damage to growth (Gandini et al., 2014).

The jatobá leaves have abaxial and adaxial epidermis covered by thick cuticle and oil glands in subepidermal position (Jorge, Melo, Reis, \& Ferro, 2006). The thick leaf cuticle and plasma membranes are barriers that limit the glyphosate activity (Denis \& Delrot, 1993). Probably for these reasons, the jatobá is tolerant to low glyphosate doses (Figure 2). Despite this tolerance, glyphosate presented deleterious effects to the growth of jatobá at 90 DAA. Glyphosate has no direct effect on photosynthesis, it acts in the plant by inhibiting the enzyme 5-Enolpiruvilshikimate-3-Phosphate synthase that catalyzes the condensation of phosphoenolpyruvate and shikimic acid (Amrhein et al., 1980). This way it prevents the synthesis of the essential aminoacids tryptophan, phenylalanine and tyrosine (Jaworski, 1972).

However, there are indirect effects of this herbicide on photosynthetic parameters (Madsen, Heitholt, Duke, Smeda, \& Streibig, 1995). One of these effects is the interruption of $\mathrm{CO}_{2}$ assimilation few hours after glyphosate application (Geiger, Kapitan, \& Tucci, 1986; Olesen \& Cedergreen, 2010). This way there is a direct influence between the $\mathrm{F}_{\mathrm{v}} / \mathrm{F}_{\mathrm{m}}$ ratio and the quantum yield of $\mathrm{CO}_{2}$ assimilation by leaf (Genty, Briantais, \& Baker, 1989). Probably this effect provided a lower ICH in plants that higher glyphosate doses were applied (Figure 2F).

Interestingly, at no assessment time significant changes in chlorophyll contents were noticed (Figure 2E). The chlorophyll fluorescence depends on the photochemical activity and leaf optical properties, which can be changed by leaf chlorophyll content (Barbagallo, Oxborough, Pallett, \& Baker 2003). However, as can be observed in this study, changes in chlorophyll fluorescence variables are not always accompanied by changes in the chlorophyll content (Figure 2). In biotypes of Lolium perennial L. with different sensitivities to glyphosate no change was found in leaf chlorophyll content, even identifying significant changes in fluorescence parameters of chlorophyll (Yanniccari et al., 2012). While in Eucalyptus spp. the chlorophyll content was affect by glyphosate doses and no difference occurred in the chlorophyll fluorescence parameters (Carvalho, Alves, \& Andrade, 2016).

Based on physiological variables $\left(\mathrm{F}_{0}, \mathrm{~F}_{\mathrm{m}}, \mathrm{F}_{\mathrm{v}} / \mathrm{F}_{\mathrm{m}}\right.$ and ETR), the jatobá plants recovered 60 days after glyphosate doses applications. Although jatobá is tolerant to glyphosate and weed competition, plants subjected to these treatments showed a lower increase in height and diameter than those grown in the absence of competition and herbicide application. Jatobá plants under 1.25 and $2.50 \mathrm{~L} \mathrm{ha}^{-1}$ of glyphosate reduces increase in height around $50 \%$, plants under 3.75 and $5.00 \mathrm{~L} \mathrm{ha}^{-1}$ reduces around $90 \%$ and plants under weed competition around $70 \%$.

\section{Acknowledgements}

This work was supported by Coordenação de Aperfeiçoamento de Pessoal de Nível Superior-Brasil (CAPES)-Financial code 001, Universidade Federal dos Vales do Jequitinhonha e Mucuri (UFVJM), Conselho Nacional de Desenvolvimento Científico e Tecnológico (CNPq), Fundação de Amparo a Pesquisa de Minas Gerais (FAPEMIG).

\section{References}

Amrhein, N., Deus, B., Gehrke, P., \& Steinrücken, H. C. (1980). The site of the inhibition of the shikimate pathway by glyphosate. Plant Physiology, 66, 830-834. https://doi.org/10.1104/pp.66.5.830

Baker, N. R. (2008). Chlorophyll fluorescence: A probe of photosynthesis in vivo. Annual Review of Plant Biology, 59, 89-113. https://doi.org/10.1146/annurev.arplant.59.032607.092759

Barbagallo, R. P., Oxborough, K., Pallett, K. E., \& Baker, N. R. (2003). Rapid, noinvasive screening for perturbations of metabolism and plant growth using fluorescence imaging. Plant Physiology, 132, 485-493. https://doi.org/10.1104/pp.102.018093

Bolhar-Nordenkampf, H. R., Long, S. P., Baker, N. R., Oquist, G., Schreiber, U., \& Lechner, E. G. (1989). Chlorophyll fluorescence as a probe of the photosynthetic competence of leaves in the field: A review of current instrumentation. Functional Ecology, 3, 497-514. https://doi.org/10.2307/2389624

Carvalho, L. B., Alves, P. L. C. A., \& Andrade, T. C. G. R. (2016). Content and fluorescence of chlorophyll in eucalypt exposed to glyphosate. Communications in Plant Sciences, 6, 7-11. https://doi.org/10.26814/ cps201607

Campoe, O. C., Iannelli, C., Stape, J. L., Cook, R. L., Mendes, J. C. T., \& Vivian, R. (2014). Atlantic forest tree species responses to silvicultural practices in a degraded pasture restoration plantation: From leaf physiology to survival and initial growth. Forest Ecology and Management, 313, 233-242. https://doi.org/10.1016/j.foreco.2013.11.016 
Campos, M. A. A., \& Uchida, T. (2002). Influência do sombreamento no crescimento de mudas de três espécies Amazônicas. Pesquisa Agropecuária Brasileira, 37, 281-288. https://doi.org/10.1590/S0100-204X2002 000300008

Costa, N. V., Erasmo, E. A. L., Queiroz, P. A., Dornelas, D. F., \& Dornelas, B. F. (2009). Efeito da deriva simulada de glyphosate no crescimento inicial de plantas de pinhão-manso. Planta Daninha, 27, 1105-1110. https://doi.org/10.1590/S0100-83582009000500024

Costa, W. S., Souza, A. L., \& Souza, P. B. (2011). Jatobá-Hymenaea courbaril L.: Ecologia, manejo, silvicultura e tecnologia de espécies nativas da Mata Atlântica. Espécies nativas da Mata Atlântica. Viçosa: Polo de Excelência em Florestas.

Denis, M. L., \& Delrot, S. (1993). Carrier-mediated uptake of glyphosate in broad bean (Vicia faba) via a phosphate transporter. Physiologia Plantarum, 8, 568-575. https://doi.org/10.1111/j.1399-3054.1993. tb02508.x

Feng, X., Yu, C., Chen, Y., Peng, J., Ye, L., Shen, T., Wen, H., \& He, Y. (2018). Non-destructive determination of shikimic acid concentration in transgenic maize exhibiting glyphosate tolerance using chlorophyll fluorescence and hyperspectral imaging. Frontiers in Plant Science, 9, 1-16. https://oi.org/10.3389/ fpls.2018.00468

Gandini, A. M. M., Santos, J. B., Andrezza, M. M. G., Santana, R. C., Cunhan, V. C., \& Valadão Silva, D. (2011). Capacidade competitiva do jatobá com adubos verdes, forrageiras e plantas daninhas. Planta Daninha, 29, 991-999. https://doi.org/10.1590/S0100-83582011000500005

Gandini, E. M. M., Santos, J. B., Gandini, A. M. M., Santanna, R. C., \& Silva, D. V. (2014). Selectivity of herbicide and rhizospheric microbial activity on Hymenaea courbaril L. seedlings. Communications in Soil Science and Plant Analysis, 45, 2235-2246. https://doi.org/10.1080/00103624.2014.931415

Geiger, D. R., Kapitan, S. W., \& Tucci, M. A. (1986). Glyphosate inhibits photosynthesis and allocation of carbon to starch in sugar beet leaves. Plant Physiology, 82, 468-472. https://doi.org/10.1104/pp.82.2.468

Genty, B., Briantais, J-M., \& Baker, N. R. (1989). The relationship between the quantum yield of photosynthetic electron transport and quenching of chlorophyll fluorescence. Biochimica et Biophysica Acta, 990, 87-92. https://doi.org/10.1016/S0304-4165(89)80016-9

Gianessi, L. P. (2008). Economic impacts of glyphosate-resistant crops. Pest Management Science, 64, $346-352$. https://doi.org/10.1002/ps.1490

Hartmann, K. C. D., Fortes, A. M. T., Cassol, F. D. R., Valmorbida, R., \& Mendonça, L. C. (2017). Atividade alelopática de espécies invasoras sobre a germinação e o desenvolvimento inicial de arbórea nativa. Floresta, 47, 229-235. http://dx.doi.org/10.5380/rf.v47i3.50222

Jaworski, E. Mode of action of N-phosphonomethylglicine: Inhibition of aromatic amino acid biosynthesis. Journal of Agricultural and Food Chemistry, 20, 1195-1198. https://doi.org/10.1021/jf60184a057

Jorge, L. I. F., Mello, A. R. P., Reis, C. M. P. V., \& Ferro, V. O. (2006). Exame microscópico de Ficus enormis (Mart. ex Miq.) Miq. (gameleira) e de Hymenaea courbaril L. var. stilbocarpa (Hayne) Lee \& Langenheim (jatob). Revista Brasileira de Farmácia, 87, 85-88.

Kottek, M., Grieser, J., Beck, C., Rudolf, B., \& Rubel, F. (2016). World map of the Köppen-Geiger climate classification updated. Meteorologische Zeitschrift, 15, 259-263. https://doi.org/10.1127/0941-2948/ 2006/0130

Lorenzi, H. (2008). Weed plants of Brazil: Terrestrial, aquatic, parasitic and toxic. Nova Odessa: Instituto Plantarum.

Madsen, K. H., Heitholt, J. J., Duke, S. O., Smeda, R. J., \& Streibig, J. C. (1995). Photosynthetic parameters in glyphosate-treated sugar beet (Beta vulgaris L.). Weed Research, 35, 81-88. https://doi.org/10.1111/ j.1365-3180.1995.tb02020.x

Malkin, R., \& Niyogi, K. (2000). Photosynthesis. In B. B. Buchanan, B. B., W. Gruissem, \& R. L. Jones (Eds.), Biochemistry and Molecular Biology of Plants (pp. 568-628). Rockville: Willey.

Maxwell, K., \& Johnson, G. N. (2000). Chlorophyll fluorescence-a practical guide. Journal of Experimental Botany, 51, 659-668. https://doi.org/10.1093/jexbot/51.345.659 
Miyake, M., Ide, K., Sasaki, K., Matsukura, Y., Shijima, K., \& Fujiwara, D. (2008). Oral administration of highly oligomeric procyanidins of Jatoba reduces the severity of collagen induced arthritis. Bioscience Biotechnology and Biochemistry, 72, 1781-178. https://doi.org/10.1271/bbb.80074

Mueller-Dombois, D., \& Ellenberg, H. (1974). Aims and methods of vegetation ecology. New York: John Wiley e Sons.

Souza, P. F., Oliveira, L. F. R., Santana, R. C., Fernandes, J. S. C., Oliveira, M. L. R., Nery, M. C., \& Pires, R. M. O. (2013). Storage of Hymenaea courbaril seeds in subzero temperature up to six months. Australian Journal of Basic and Applied Sciences, 7, 147-153.

Souza, P. F., Santana, R. C., Fernandes, J. S. C., Oliveira, L. F. R., Machado, E. L. M., Nery, M. C., \& Oliveira, M. L. R. (2015). Germinação e crescimento inicial entre matrizes de duas espécies do gênero Hymenaea. Floresta e Ambiente, 22, 532-540. https://doi.org/10.1590/2179-8087.067613

Olesen, C. F., \& Cedergreen, N. (2010). Glyphosate uncouples gas exchange and chlorophyll fluorescence. Pest Management Science, 66, 536-542. https://doi.org/10.1002/ps.1904

Rochaix, J-D. (2011). Reprint of: Regulation of photosynthetic electron transport. Biochimica et Biophysica Acta, 1807, 375-383. https://doi.org/10.1016/j.bbabio.2011.05.009

Yanniccari, M., Tambussi, E., Istilart, C., \& Castro, A. M. (2012). Glyphosate effects on gas exchange and chlorophyll fluorescence responses of two Lolium perenne L. biotypes with differential herbicide sensitivity. Plant Physiology and Biochemistry, 57, 210-217. https://doi.org/10.1016/j.plaphy.2012.05.027

Zobiole, L. H. S., Kremer, R. J., Oliveira-Júnior, R. S., \& Constantin, J. (2011). Glyphosate affects chlorophyll, nodulation and nutrient accumulation of "second generation" glyphosate-resistant soybean (Glycine max L.). Pesticide Biochemistry and Physiology, 99, 53-60. https://doi.org/10.1016/j.pestbp.2010.10.005

Zuba-Junior, G. R., Sampaio, R. A., Pereira, C. M., Prates, F. B. S., Fernandes, L. A., \& Alvarenga, I. C. A. (2010). Crescimento do jatobá e de leguminosas arbóreas em diferentes espaçamentos, em área degradada. Revista Caatinga, 23, 63-68.

\section{Copyrights}

Copyright for this article is retained by the author(s), with first publication rights granted to the journal.

This is an open-access article distributed under the terms and conditions of the Creative Commons Attribution license (http://creativecommons.org/licenses/by/4.0/). 